\title{
Octylcaffeate Induced Apoptosis in Human Leukemia U937 Cells
}

\author{
Mayuko Ujibe, ${ }^{a}$ Syu-ichi Kanno, ${ }^{a}$ Yu OsanaI,${ }^{a}$ Kimiko KoIwaI, ${ }^{a}$ Takaharu Ohtake, ${ }^{a, b}$ \\ Katsuhiko Kimura, ${ }^{b}$ Kohji UwaI, ${ }^{c}$ Mitsuhiro TAKeshita, ${ }^{c}$ and Masaaki IshiKawA ${ }^{*, a}$ \\ ${ }^{a}$ Department of Pharmacology and Toxicology, Cancer Research Institute, Tohoku Pharmaceutical University; \\ ${ }^{b}$ Department of Pharmacology and Pharmacy, Tohoku Pharmaceutical University; Sendai 981-8558, Japan: and ${ }^{c}$ Tohoku \\ Employees' Pension Welfare Hospital; Sendai 983-0005, Japan. Received May 11, 2005; accepted September 14, 2005
}

\begin{abstract}
We found that octylcaffeate, a semisynthetic caffeic acid derivative, strongly inhibited the growth of human histiolytic lymphoma U937 cells in a dose- and time-dependent manner via apoptosis. Octylcaffeate induced the fragmentation of DNA into multiples of $180 \mathrm{bp}$ (an apoptotic DNA ladder) and condensation of chromatin, and increased the percentage of hypodiploid cells detected with a flow cytometer. DNA fragmentation induced by octylcaffeate was inhibited by pretreatment with Z-DEVD-FMK and Z-Asp-CH $\mathrm{H}_{2} \mathrm{D}-\mathrm{CB}$, an inhibitor of caspase, clearly showing that the mode of cell death is apoptotic. These findings suggest that the cytotoxicity of octylcaffeate involves the induction of apoptosis.
\end{abstract}

Key words octylcaffeate; apoptosis; caspase; U937

Apoptosis is a specific process that leads to programmed cell death through the activation of an evolutionary conserved intracellular pathway distinct from necrosis, and it is essential in the homeostasis of normal tissues such as the gastrointestinal tract, the immune system and skin. ${ }^{1)}$ Dysregulation of the apoptotic pathway, however, is involved in many pathological conditions such as cancer and neurodegenerative diseases, ${ }^{2)}$ and increasing evidence suggests that the processes of neoplastic transformation, progression and metastasis involve alterations of normal apoptotic pathways. ${ }^{1)}$ Cell death from apoptosis is characterized by microvilli, cell shrinkage, chromatin condensation, nuclear collapse and cellular fragmentation into apoptotic-bodies. In most cases, these morphological changes are accompanied by internucleosomal DNA fragmentation. A family of caspases play a pivotal role in the execution of apoptosis. Because many chemotherapeutic drugs have been shown to induce apoptosis in cancer cells, ${ }^{3)}$ the therapeutic application of apoptosis has currently been used as a model for developing antitumor drugs. ${ }^{4)}$ Caspase-3 has been shown to play an important role in antitumor drug-induced apoptosis. ${ }^{4)}$

Octylcaffeate is a semi-derived compound from caffeic acid. Caffeic acid and some of its derivatives have a broad spectrum of biological activities including antioxidative, anti-infammatory and antiviral properties. ${ }^{5-7)}$ Caffeic acid phenethyl ester (CAPE), which was isolated from propolis, demonstrated an ability to induce apoptosis in tumor or virally transformed cells but not in parental normal cells. $\left.{ }^{89}\right)$ Because of CAPE's simplicity of structure and interesting cytotoxic properties, its antitumor activity was studied further.

Recently, we synthesized octylcaffeate and found that it exhibited strong cytotoxicity in leukemia cells. Therefore, in the present study, the mechanism of octylcaffeate-induced cytotoxicty was investigated in the human histiolytic lymphoma cell line U937.

\section{MATERIALS AND METHODS}

Chemicals Octylcaffeate had been synthesized from caffeic acid by exhaustive octanol-esterization according to Etzenhouser et al. $^{10)}$ In this study, octylcaffeate and CAPE (Sigma, St. Louis, MO, U.S.A.) were diluted in dimethylsul- foxide (DMSO) to make stock solutions of $1 \mathrm{~mm}$, kept at $4{ }^{\circ} \mathrm{C}$ and filtrated with a sterile filter just before use, and then added at the appropriate final concentrations to cultures of cells. Control cells were treated with the same amount of vehicle alone. The final DMSO concentrations never exceeded $0.5 \%(\mathrm{v} / \mathrm{v})$. Other reagents used in this research were purchased from Nacalai Tesque (Kyoto, Japan) and Wako Pure Chemical Industries Co. (Osaka, Japan) unless otherwise specified.

Cell Culture and Treatment Cells (U937, HL-60, K562, P388, Hep G2, Hep 3B, and WI-38VA13) were obtained from the Cell Resource Center for Biomedical Research, Tohoku University (Sendai, Japan) or Japanese Research Resources Bank (Tokyo, Japan). The cells were grown in RPMI 1640 medium (Iwaki Co., Ltd., Tokyo, Japan) supplemented with 100 units $/ \mathrm{ml}$ penicillin, $100 \mu \mathrm{g} / \mathrm{ml}$ streptomycin and $10 \%$ heat-inactivated fetal bovine serum at $37{ }^{\circ} \mathrm{C}$ under a humidified $95 \%$ air $5 \% \mathrm{CO}_{2}$ atmosphere, and passaged every $3 \mathrm{~d}$. After the addition of octylcaffeate to U937 cells $\left(4 \times 10^{5}\right.$ cells $\left./ \mathrm{ml}\right)$ for the appropriate duration, the cells were washed three times with ice-cold phosphate saline (PBS) before the next treatment.

Cell Proliferation Assay An MTT assay was employed to assess the viable cell number quantitatively with our previously described method. ${ }^{11)}$ In brief, cells were seeded at $4 \times 10^{4} / 100 \mu \mathrm{l}$ per well in a 96 -well plate and treated with various concentrations of octylcaffeate or vehicle as described in the figure legends. MTT (final concentration, $5 \mathrm{mg} / \mathrm{ml}$ ) was added to each well: after incubation for $4 \mathrm{~h}$ at $37^{\circ} \mathrm{C}$, the formazan crystals produced by viable cells were dissolved with $100 \mu \mathrm{l}$ of $0.04 \mathrm{~N} \mathrm{HCl}$ containing isopropanol. The absorbance at $590 \mathrm{~nm}$ was measured using an Inter-med model NJ-2300 Microplate Reader. The viable cell number was expressed as a percentage of control cells, measured as $100 A_{590, \text { octylcaffeate-treated }} / A_{590, \text { control. }}$.

Morphological Changes in U937 Cells Treated with Octylcaffeate Cells were washed twice with PBS and then stained for $10 \mathrm{~min}$ at room temperature with PBS containing $5 \mu \mathrm{m}$ Hoechst 33342. Morphologically, cells were examined under a model TE 300 fluorescence microscope (Nikon, Tokyo) when the nuclei exhibited typical apoptotic features such as chromatin condensation and fragmentation. Apop- 
totic cells were quantified using a fluorescence microscope by counting 200 cells/microscopic field (at $100 \times$ ) in three fields in each sample as reported earlier. ${ }^{11)}$ The quantitative data presented are the mean percentage of apoptotic cells in triplicate samples for each treatment.

Detection of DNA Fragmentation The DNA ladder was detected by agarose gel electophoresis as described previously. ${ }^{12)}$ U937 cells incubated with octylcaffeate were harvested and lysed with lysis buffer (1\% IGEPL CA-630 in $20 \mathrm{~mm}$ EDTA, and $50 \mathrm{~mm}$ Tris- $\mathrm{HCl}, \mathrm{pH} 7.5$ ) and 1\% SDS. They were then incubated for $3 \mathrm{~h}$ with proteinase $\mathrm{K}$ (final concentration, $100 \mu \mathrm{g} / \mathrm{ml}$ ) at $56{ }^{\circ} \mathrm{C}$, before being digested overnight with RNase A (final concentration, $10 \mu \mathrm{g} / \mathrm{ml}$ ) at $37^{\circ} \mathrm{C}$ to obtain the lysate. After each supernatant was extracted twice with phenol-chloroform-isoamyl alcohol $(25: 24: 1)$, DNA was precipitated with a double volume of ethanol and dissolved in a gel loading buffer. DNA fragmentation was detected by electrophoresis on $1.4 \%$ agarose gels containing ethidium bromide, visualized under UV light, and photographed.

Flow Cytometric Analysis Octylcaffeate-treated cells $\left(1 \times 10^{6}\right)$ were freshly harvested, and pellets were mixed with a $1: 1(\mathrm{v} / \mathrm{v})$ mixture of PBS and $0.2 \mathrm{M} \mathrm{Na} \mathrm{HPO}_{4}-0.1 \mathrm{M}$ citric acid ( $\mathrm{pH} 7.5$ ), and fixed with ice-cold ethanol at $4{ }^{\circ} \mathrm{C}$ for $1 \mathrm{~h}$. The cells were washed twice with PBS and resuspended in $1 \mathrm{ml}$ of a staining solution containing $10 \mu \mathrm{g} / \mathrm{ml}$ propidium iodide. The cell suspensions were incubated at room temperature for $1 \mathrm{~h}$ and 20000 cells were analyzed on a FACScalibur flow cytometer (Becton-Dickinson).

Measurement of Caspase-3 Activity Octylcaffeatetreated cells $\left(1 \times 10^{6}\right)$ were harvested and washed once with cold PBS. Then, cell pellets were lysed in buffer containing 20 mм Hepes (pH 7.4), $100 \mathrm{~mm} \mathrm{NaCl,} \mathrm{0.5 \%} \mathrm{(v/v)} \mathrm{NP-40} \mathrm{and}$ $10 \mathrm{~mm}$ DTT on ice for $30 \mathrm{~min}$. After centrifugation at $13000 \mathrm{rpm}$ for $5 \mathrm{~min}$ at $4{ }^{\circ} \mathrm{C}$ using an Eppendorf centrifuge, supernatants were collected and added with Ac-DEVD- pNA to a final concentration of $500 \mu \mathrm{M}$. Optical density at $405 \mathrm{~nm}$ was measured after incubation at $37^{\circ} \mathrm{C}$ for $30 \mathrm{~min}$.

Statistics The data were expressed as the mean \pm S.E. and evaluated using Student's $t$-test with SPSS software. Data was considered statistically significant when the $p$ value was less than 0.05 .

\section{RESULTS AND DISCUSSION}

The MTT assay was used to evaluate the cytotoxic effect of octylcaffeate on U937 cells. Cells were exposed to various concentrations of octylcaffeate for specific periods and viability was assayed. Figure 1A shows that the viable cell number decreased as the concentration of octylcaffeate or CAPE increased, suggesting that octylcaffeate or CAPE induced cell death in a concentration-dependent manner. Octylcaffeate $\left(\mathrm{IC}_{50}: 25.5 \mu \mathrm{M}\right)$ showed stronger activity than the positive control, CAPE $\left(\mathrm{IC}_{50}: 155.9 \mu \mathrm{M}\right)$, but caffeic acid was not cytotoxic at the indicated dose after $24 \mathrm{~h}$.

Figure 1B shows that the viable cell number decreased in a time-dependent manner. These results indicate that the cytotoxic effect of octylcaffeate on U937-6 cells was dependent on both concentration and time.

Statistical analysis indicated that the concentration causing $50 \%$ growth-inhibition $\left(\mathrm{IC}_{50}\right)$ for $24 \mathrm{~h}$ was $25 \mu \mathrm{M}$. Therefore,
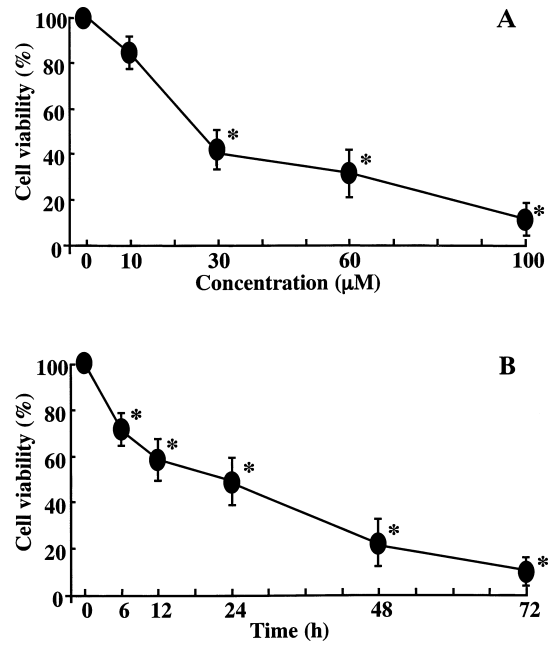

Fig. 1. Dose- (A) and Time- (B) Dependent Cytotoxicity of Octylcaffeate in U937 Cells

The cells were treated for $24 \mathrm{~h}$ with octylcaffeate at the indicated doses (A) and treated with $25 \mu \mathrm{M}$ of octylcaffeate at each time point (B). Control cells were treated with DMSO. Cell viability was determined by MTT assay. Results are expressed as a percentage of the corresponding control and are the mean. S.E.M. was usually within $10 \%$ of the mean value $(n=6)$. Asterisks denote a significant difference from the control $(p<0.05$, Student's $t$-test).

Table 1. Inhibitory Effects of Octylcaffeate on the Growth of Human Cancer Cells

\begin{tabular}{llc}
\hline \multicolumn{1}{c}{ Cell name } & \multicolumn{1}{c}{ Characteristics } & \multicolumn{1}{c}{$\mathrm{IC}_{50}(\mu \mathrm{M})$} \\
\hline U937 & Promyelocytic leukemia & $25.5(15.6-41.8)$ \\
HL-60 & Promyelocytic leukemia & $31.4(24.1-40.9)$ \\
K562 & Erythroleukemia & $13.5(10.2-18.0)$ \\
P388 & Lymphoid neoplasma & $38.7(21.9-68.3)$ \\
Hep G2 & Human hepatoma, p53 (wt) & $50.3(36.8-68.8)$ \\
Hep 3B & Human hepatoma, p53 (negative) & $34.2(29.1-40.1)$ \\
WI-38VA13 & Human fibroblast & $22.0(15.7-30.8)$ \\
\hline
\end{tabular}

Cells were treated with octylcaffeate for $24 \mathrm{~h} . \mathrm{IC}_{50}$ is defined as the concentration which resulted in a $50 \%$ decrease in cell number. Cell viability was determined as in Fig. 1. In parentheses are indicated $95 \%$ confidence limits.

we examined the effects of octylcaffeate on the growth of various human cancer cells. The $\mathrm{IC}_{50}$ values are listed in Table 1. From this table, it can be seen that octylcaffeate strongly inhibited the growth of all lines of cells derived from human tumors examined. The $\mathrm{IC}_{50}$ values ranged from $13-50 \mu \mathrm{M}$ for the various lines of cancer cells. Among them, K562 cells seemed to be highly susceptible to octylcaffeate treatment, with an $\mathrm{IC}_{50}$ of $13.5 \mu \mathrm{M}$.

Cells die by either necrosis or apoptosis. Apoptosis is distinguished from necrosis by characteristic morphological and biochemical changes, including condensation and fragmentation of the chromatin, the activation of certain proteases and nucleases, and the appearance of cells at sub- $\mathrm{G}_{0} / \mathrm{G}_{1}$ (the subdiploid peak). ${ }^{13,14)}$ To determine whether the features of the cell death induced by octylcaffeate were those of apoptosis or necrosis, we analyzed the morphological and biochemical change of DNA in U937 cells that had been treated with $25 \mu \mathrm{M}$ octylcaffeate for various periods. Morphological observation of octylcaffeate-treated cells using Hoechst 33342 staining revealed marked chromatin condensation and apoptotic body formation (Fig. 2A), demonstrating that octylcaffeate induces apoptosis in U937 cells. In order to determine whether or not the polymerization of actin plays a role in the 
(A)
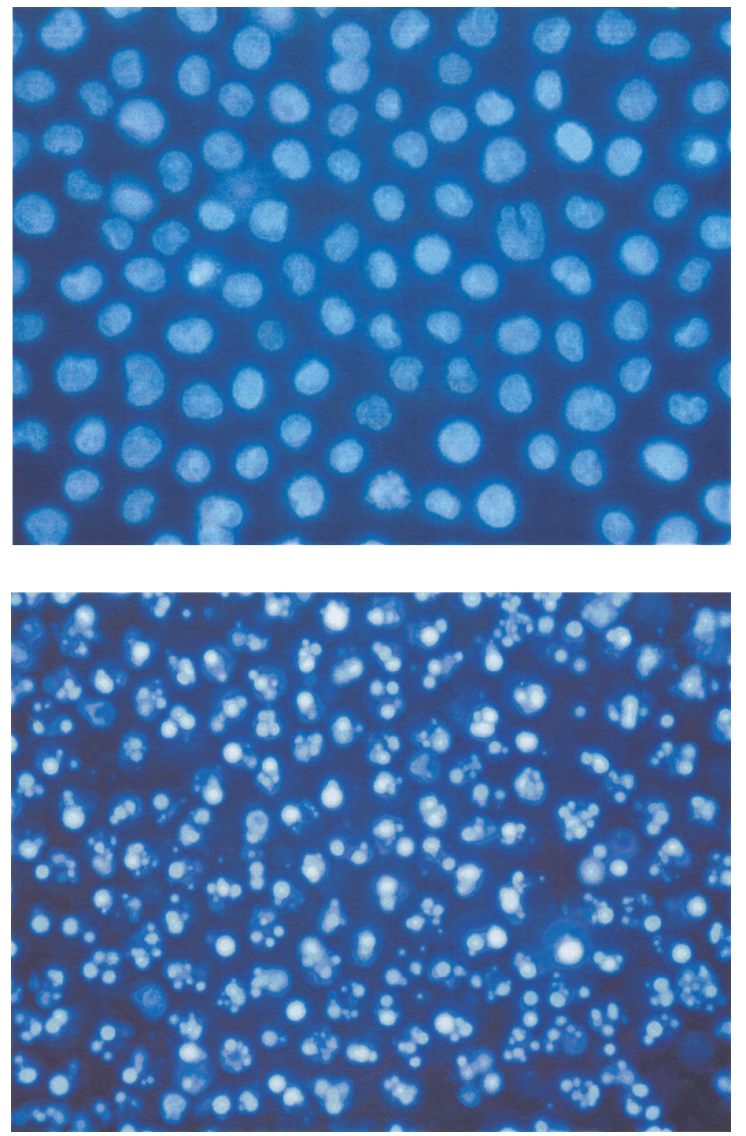

(B)

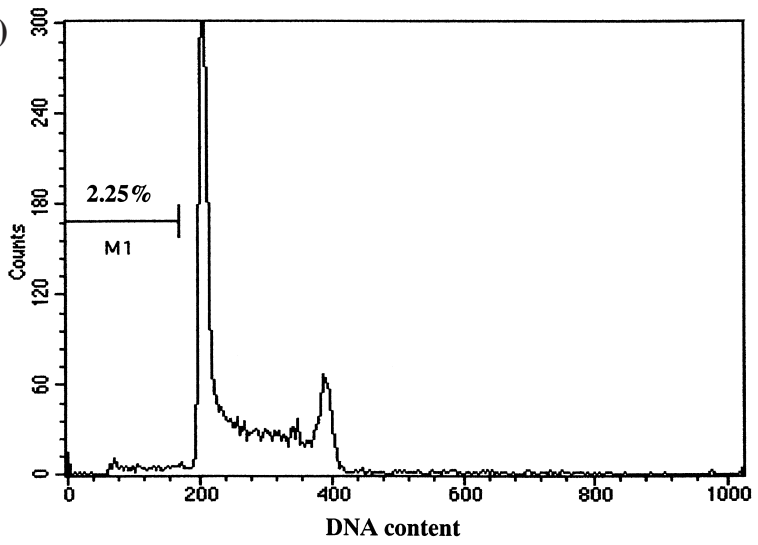

b

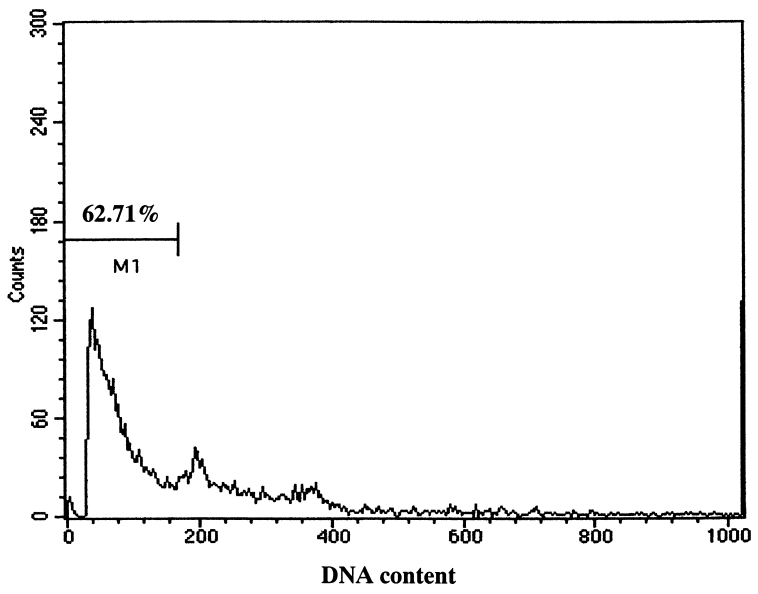

Fig. 2. Octylcaffeate Induces Apoptosis in U937 Cells

Cells were treated with DMSO alone (control; upper panel) or $25 \mu \mathrm{M}$ of octylcaffeate (lower panel) for $24 \mathrm{~h}$. (A) Fluorescence of micrographs of U937 cells. The cells were stained with Hoechst 33258 and examined by fluorescence microscope. Magnification, $\times 400$. (B) Determination of sub-G1 cells by flow cytometric analysis. The PI-stained cells were analyzed for DNA content by flow cytometry. M1 indicates the apoptotic peak representing the cells with a sub-diploid content. Cell debris from the analysis by conventional gating of forward scatter versus side scatter dot plots.

induction of apoptosis by octylcaffeate, we tested U937 cells with octylcaffeate in the presence and absence of cytochalasin B, which inhibits the binding of monomers of G-actin to F-actin. The nuclei of U937 cells that had been treated with octylcaffeate were condensed and fragmented in both the presence and absence of cytochalasin B (results not shown). These results indicated that the polymerization of Gactin was needed for the induction of apoptosis by octylcaffeate, even though changes in the distribution of actin were induced by octylcaffeate. Flow cytometric analysis revealed the hallmark features of apoptosis, with the appearance of sub-diploid DNA (the accumulation of cells at sub- $\mathrm{G}_{0} / \mathrm{G}_{1}$ ) (Fig. 2B). The sub-diploid peak began to appear in the distribution of DNA content after treatment with octylcaffeate for $24 \mathrm{~h}$ and increased with time. Quantitative analysis revealed that octylcaffeate induced the apoptosis of U937 cells in a time-dependent manner (results not shown). Furthermore, as shown in Fig. 3, treatment of U937 cells with $25 \mu \mathrm{M}$ octylcaffeate for more than $4 \mathrm{~h}$ resulted in the ladder pattern of DNA fragments that is characteristic of apoptosis.

Many papers reported that internucleosomal DNA fragmentation is not essential in apoptotic cell death, and can accompany necrotic cell death, suggesting that internucleosomal DNA fragmentation may not be enough of an indicator of apoptotic cell death. ${ }^{15,16)}$ It is, however, clear that the central mechanism of apoptosis is evolutionarily conserved and

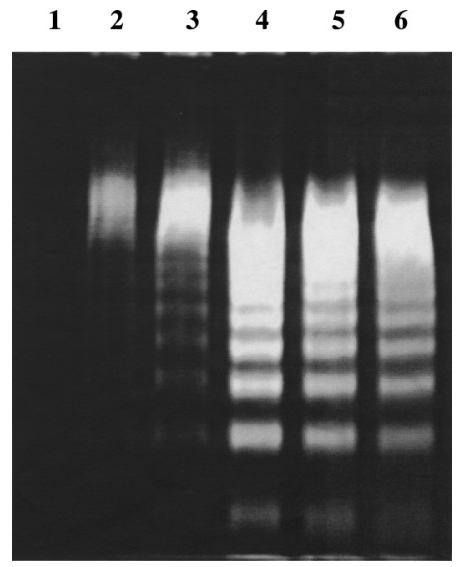

Fig. 3. DNA Fragmentation Induced in U937 Cells by Octylcaffeate

U937 cells were treated with $25 \mu \mathrm{M}$ of octylcaffeate for 0 (Lane 1), 2 (Lane 2), 4 (Lane 3), 6 (Lane 4), 8 (Lane 5), and $12 \mathrm{~h}$ (Lane 6). At the times indicated, the cells were lyzed and DNA prepared. DNA fragmentation was analyzed by agarose gel electrophoresis and staining with ethidium bromide.

the activation of caspases is an essential step in this complex pathway. $^{17)}$

In order to determine which caspase is activated during the apoptosis induced by octylcaffeate, we used Ac-DEVD-pNA, a specific colorimetric substrate of caspase-3. ${ }^{18)}$ Figure 4 shows that caspase- 3 activity begins to increase after $4 \mathrm{~h}$ of 

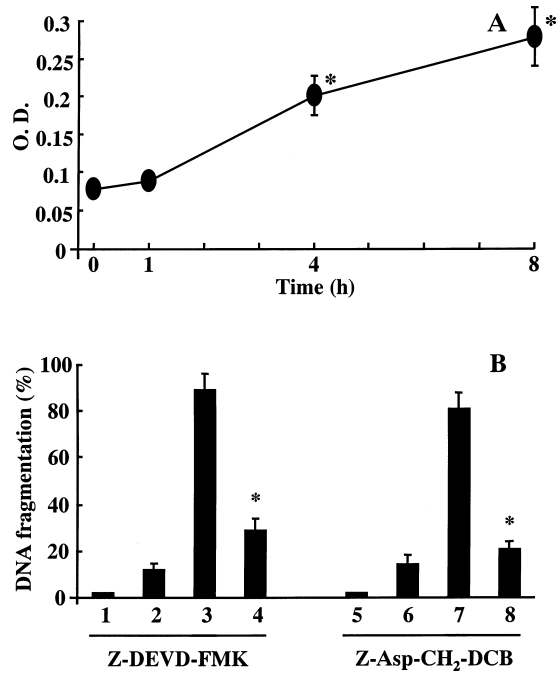

Fig. 4. Analysis of the Activity of Caspase-3 Protease during Apoptosis Induced by Octylcaffeate

(A) Cells were treated with $25 \mu \mathrm{M}$ octylcaffeate for the indicated times and caspase-3 activity was measured. Data indicate the O.D. values, and are expressed as the mean of 3 experiments. S.E.M. was usually within $10 \%$ of the mean value. (B) Cells were incubated for $1 \mathrm{~h}$ with $100 \mu \mathrm{M}$ of inhibitor (columns $2,4,6,8$ ), and then for an additional 3 h with $25 \mu \mathrm{M}$ octylcaffeate (columns 4,8 ). Columns 1 and 5, control cells; columns 3 and 7 , octylcaffeate-treated cells without pretreatment with an inhibitor. The number of apoptotic cells, defined as cells with condensed and fragmented nuclei, was evaluated on $\mathrm{H} 33258$-stained preparations and expressed as a percentage of the total number of cells in untreated cultures. The data are presented as the means \pm S.E. of the results for three independent experiments. $*$ Significantly different from the corresponding inhibitor of caspase at $p<0.05$.

octylcaffeate treatment and reaches a maximal level after $8 \mathrm{~h}$. The pattern of the increase in caspase- 3 activity was well correlated with that of the octylcaffeate-induced fragmentation of DNA. To confirm the involvement of caspase in octylcaffeate-induced apoptosis, we used two types of inhibitor, benzyloxycarbonyl-Asp-Glu-Val-Asp-fluoromethylketone (Z-DEVD-FMK) and benzyloxycarbonyl-Asp- $\mathrm{CH}_{2} \mathrm{OCO}-$ 2,6-dichlorobenzene (Z-Asp- $\mathrm{CH}_{2} \mathrm{DCB}$ ). Z-DEVD-FMK inhibits caspase- 3 activity specifically and Z-Asp- $\mathrm{CH}_{2} \mathrm{DCB}$ is a broad spectrum inhibitor of the caspase family. Both inhibitors almost completely inhibited the DNA fragmentation that was otherwise induced by octylcaffeate (Fig. 4). The data of Fig. 4, therefore, clearly prove that octylcaffeate-induced cell death is mediated by activation of caspases which occurs upstream of the DNA fragmentation. These results match well the report of Shimizu and Pommier which showed that z-VAD-fmk blocked all features of apoptosis induced by camptotecin in leukemia cells. ${ }^{19)}$

Apoptosis of tumor cells can be triggered by various treatments such as irradiation, Fas (a cell surface molecule mediating apoptosis) ligand, and antitumor drugs., ${ }^{3,20)}$ The regulation of apoptosis require two major protein families, namely, Bcl-2-related gene products and caspases. ${ }^{17}$ ) The growing Bcl-2 protein family contains several homologous proteins including antiapoptotic proteins (Bcl-2, Bcl-xL, etc.) and proapoptotic proteins (Bax, Bad, etc.). ${ }^{17}$ CAPE induces apoptosis in certain tumor cells; its action is accompanied by the activation of caspase-3, down-regulation of Bcl-2, and up-regulation of Bax. ${ }^{21)}$ Apoptosis, via numerous triggers including the binding of ligands to death receptors is antagonized by the activation of $\mathrm{NF} \kappa \mathrm{B}$, and potentiated by its inhibition. Moreover, CAPE not only inhibits NF $\kappa$ B activity but also activates the Fas death receptor. ${ }^{22}$ Further studies are necessary to evaluate the involvement of the caspase cascade, cancer-associated genes, and the MAP cascade in the induction of apoptosis by octylcaffeate.

In the present study, we found that octylcaffeate was a potent inhibitor of the growth of cancer cells derived from various human solid tumors. The death of U937 cells induced by octylcaffeate was proved to be due to apoptosis by demonstration of the induction of caspase-3 activity, and of the fragmentation of nuclei and DNA. Octylcaffeate was shown to induce apoptosis, cellular suicide, of cancer cells suggesting that it may be used efficiently for the treatment of cancer.

Acknowledgments This study was support in part by ChatBlanc Inc. (Tokyo, Japan).

\section{REFERENCES}

1) Bold R. J., Termuhlen P. M., McConkey D. J., Surg. Oncol., 6, 133142 (1997).

2) Hetts S. W., JAMA, 279, 300-307 (1998).

3) Kaufmann S. H., Earnshaw W. C., Exp. Cell Res., 256, $42-49$ (2000).

4) Barmford M., Walkinshaw G., Brown R., Exp. Cell Res., 256, 1-11 (2000).

5) Fesen M. R., Pommier Y., Leteurtre E., Hiroguchi S., Yung J., Kohn K. W., Biochem. Pharmacol., 48, 595-608 (1994).

6) Orban Z., Mitsiades N., Burke T. R., Tsokos M., Chrousos G. P., Neuroimmuno-modulation, 7, 99-105 (2000).

7) Hsiao G., Shen M., Chang W., Chen Y., Pan S., Kuo Y., Chen T., Shen J., Biochem. Pharmacol., 65, 1383-1392 (2003).

8) Su Z., Lin J., Grunberger D., Fisher P. B., Cancer Res., 54, 18651870 (1994).

9) Chen J. H., Shao Y., Huang M. T., Chin C. K., Ho C. T., Cancer Lett., 108, $211-214$ (1996)

10) Etzenhouser B., Hansch C., Kapur S., Selassie C. D., Bioorg. Med. Chem., 9, 199-209 (2001).

11) Kanno S., Shouji A., Asou K., Ishikawa M., J. Pharmacol. Sci., 92, $166-170$ (2003).

12) Kanno S., Matukawa E., Miura A., Shouji A., Asou K., Ishikawa M., Biol. Pharm. Bull., 26, $964-968$ (2003).

13) Ellis R. E., Yuan J., Horvitz H. R., Annu. Rev. Cell Biol., 7, 663-698 (1991).

14) Kerr J. F. R., Winterford C. M., Harmon B. V., Cancer, 73, 2013 2026 (1994).

15) Schulze-Osthoff K., Walczak H., Droge W., Krammer P. H., J. Cell Biol., 127, 15-20 (1994).

16) Cohen G. M., Sun X. M., Snowden R. T., Dinsdale D., Skilleter D. N., Biochem. J., 286, 331-334 (1992).

17) Thornberry N. A., Lazebnik Y., Science, 281, 1312-1316 (1998).

18) Datta R., Banach D., Kojima H., Talanian R. V., Alnemri E. S., Wong W. W., Kufe D. W., Blood, 88, 1936-1943 (1996).

19) Shimizu T., Pommier Y., Leukemia, 11, 1238-1244 (1997).

20) Strand S., Hofmann W., Hug H., Muller M., Otto G., Strand D., Marian S. M., Stremmel W., Krammer P. H., Galle P. R., Nat. Med., 2 , $1361-1366$ (1996).

21) Chen Y. J., Shiao M. S., Hsu M. L., Sai T. H., Wang S. Y., J. Argic. Food Chem., 49, 5615-5619 (2001).

22) Watanabe M., Hishikawa K., Takayanagi A., Shimizu N., Nakaki T., J. Biol. Chem., 279, 6017-6026 (2004). 